\title{
THE EFFECT OF DIFFERENT STARTER CULTURES OF Lactobacillus paracasei M104 AND Pediococcus pentosaceus M103 ON THE PHYSICOCHEMICAL AND MICROBIAL QUALITIES OF FERMENTED GOAT MILK
}

\author{
Widodo Widodo*, Aryo Pujo Sakti, Ari Surya Sukarno, Endang Wahyuni, Nurliyani \\ Department of Animal Products Technology, Faculty of Animal Science, Universitas Gadjah Mada, Jl Fauna 3, \\ Bulaksumur, Yogyakarta 55281, Indonesia \\ *Corresponding author: widodohs@ugm.ac.id
}

Accepted 8 May 2019; Revised 13 September 2019

Published 17 October 2019

\begin{abstract}
The utilization of starter cultures is vital for dairy fermentation industries. Lactobacillus paracasei M104 and Pediococcus pentosaceus M103 have been isolated from goat milk and were demonstrated to acidify goat milk during fermentation. This study was conducted to compare the physicochemical and microbial qualities of goat milk fermented using these starter cultures either as a single starter or combined in goat milk. The treatments were L. paracasei M104 (Lp) and P. pentosaceus M103 (Pp) as single starter culture fermentation and combined $(\mathrm{Lp} / \mathrm{Pp})$ fermentation at a ratio of 1:1 at $6 \%$ inoculation (v/v). For control treatment, goat milk was fermented using yogurt starter, i.e., a combination culture of Streptococcus thermophilus and L. bulgaricus $(\mathrm{St} / \mathrm{Lb})$ at a ratio of $1: 1$ at $6 \%(\mathrm{v} / \mathrm{v})$. The fermentation was performed by incubating the inoculated goat milk at $37^{\circ} \mathrm{C}$ for $18 \mathrm{~h}$. The $\mathrm{pH}$ and degree of acidity were measured every $2 \mathrm{~h}$ during the fermentation process, whereas the physicochemical ( $\mathrm{pH}$, degree of acidity, lactose, protein, and viscosity) and microbial (total lactic acid bacteria/LAB) qualities were measured after the fermentation process. Data analysis revealed that the different starter cultures had no significant effect $(\mathrm{P}>0.05)$ on the $\mathrm{pH}$ and degree of acidity, lactose and protein content, viscosity, and total LAB content. The goat milk fermented in this study had an average $\mathrm{pH}$ of $4.41 \pm 0.11$ and a degree of acidity of $1.26 \pm 0.05 \%$, a lactose content of $5.47 \pm$ $0.80 \%$, a protein content of $6.69 \pm 1.52 \%$, a viscosity of $1217 \pm 395 \mathrm{cP}$, and a total LAB content of $9.57 \pm 1.49 \log \mathrm{CFU} / \mathrm{mL}$. In conclusion, goat milk fermented using both single and combined starter cultures of $L$. paracasei M104 and $P$. pentosaceus M103 exhibited similar physicochemical and microbial qualities and required longer fermentation time compared with the control.
\end{abstract}

Keywords: Goat milk; starter cultures; L. paracasei M104; P. pentosaceus M103 


\section{INTRODUCTION}

Goat milk is one of the alternative diets that has several advantages compared with cow milk. Goat milk is known to have smaller $(2.5-3.5 \mu \mathrm{m})$ and well-dispersed milk fat globules that make the product easier to digest, and it also contains abundant antibacterial compounds (Jennes, 1999; Park et al., 2007). Goat milk also contains a higher amount of minerals, calcium, phosphorus, and vitamins A, E, and B complex than cow milk (Jennes, 1980; Park and Haenlein, 2013). Furthermore, the high amount of short-chain fatty acids present in goat milk, especially propionate, can inhibit the synthesis of mevalonic acid, thereby reducing the synthesis of endogenous cholesterol and the total blood cholesterol levels (Haenlein, 2004; Park and Haenlein, 2013).

Fermentation is one of the milk processing methods that produces a fresh and sour product through the activity of the added starter cultures. During fermentation, lactose is metabolized by bacteria through processes catalyzed by enzymes into glucose and galactose, which are then metabolized through glycolysis into organic acids in the form of lactic acid or acetic acid (Walstra et al., 1999). On the other hand, the produced organic acids can also reduce the $\mathrm{pH}$ of milk until it reaches an isoelectric condition and causes casein coagulation. The low $\mathrm{pH}$ of the fermented milk can inhibit the growth of spoilage bacteria, thereby prolonging the shelf-life of the product (Walstra et al., 2006). Furthermore, the ability of lactic acid bacteria (LAB) to produce bacteriocin is also known to contribute to the prolongation of the shelf life of fermented milk (Jack et al., 1995;

*Corresponding author:

Widodo Widodo

Email: widodohs@ugm.ac.id

Department of Animal Products Technology, Faculty of Animal Science, Universitas Gadjah Mada, Jl. Fauna 3, Bulaksumur, Yogyakarta 55281, Indonesia
Klaenhammer, 1993). LAB comprise a group of bacteria that are commonly used as a starter culture in fermented milk products. These bacteria have fulfilled the food safety criteria and are generally considered as safe for consumption. The widely used LAB in milk fermentation include Lactobacillus, Streptococcus, Leuconostoc, and Pediococcus (Von Wright and Axelsson, 2012). These bacteria are also used in various probiotic products (Parvez et al., 2006). To fulfill the probiotic requirements, it is recommended that $\mathrm{LAB}$ be isolated from their original source. Widodo et al. (2016) isolated Lactobacillus paracasei M104 and Pediococcus pentosaceus M103 from Etawah crossbred (PE) goat milk. Both bacteria have been evaluated as starter cultures and have demonstrated the ability to acidify the media during fermentation (Widodo et al., 2016). However, an optimal result was not obtained with the use of both these bacteria for the fermentation of PE goat milk, and the fermentation process required a longer time to reduce the $\mathrm{pH}$ of milk to 4.5 (Widodo et al., 2016). Therefore, this study was conducted to compare the acidifying capabilities between combined $L$. paracasei M104 and P. pentosaceus M103 cultures and single culture fermentation and to evaluate the physicochemical and microbial qualities of the produced fermented milk.

\section{MATERIALS AND METHODS}

This study was conducted at the Laboratory of Milk and Egg Technology, Faculty of Animal Science, Universitas Gadjah Mada, from August 2017 to February 2018. Fresh PE goat milk was obtained from "Bumiku Hijau" farm in

\footnotetext{
How to cite:
}

Widodo., Sakti, A. P., Sukarno, A. S., Wahyuni, E., Nurliyani. (2019). The Effect of Different Starter Cultures of Lactobacillus paracasei M104 and Pediococcus pentosaceus M103 on the Physicochemical and Microbial Qualities of Fermented Goat Milk. Jurnal Ilmu dan Teknologi Hasil Ternak, 14 (2), 70-77 
Sleman, Yogyakarta. The skim milk powder "Lactona Skim" manufactured by PT. Mirota Kampus was used in this study. $L$. paracasei M104 and P. pentosaceus M103 that were isolated from PE goat milk in a previous study (Widodo et al., 2016) were used as starter cultures in this study, whereas L. bulgaricus FNCC-0041 and Streptococcus thermophilus FNCC-0040 used for the control treatment were obtained from the Center of Food and Nutrition Studies, Universitas Gadjah Mada. The medium used for microbial cultivation was de Man, Rogosa, and Sharpe (MRS) medium.

\section{Preparation of Starter Cultures}

$S$. thermophilus FNCC-0040, $L$. bulgaricus FNCC-0041, L. paracasei M104, and $P$. pentosaceus M103 cultures were grown in MRS medium that was presterilized at $121^{\circ} \mathrm{C}$ and 15 psi for $15 \mathrm{~min}$. The inoculated media were then incubated at $37^{\circ} \mathrm{C}$ for $18 \mathrm{~h}$. The starter cultures were prepared as described by Ouwehand et al. (2001), which included the preparation of mother and bulk starter cultures. The mother starter culture was prepared by inoculating $>10 \%(\mathrm{v} / \mathrm{v})$ bacteria to $100 \mathrm{~mL}$ sterilized goat milk that was added with $4 \%$ (w/v) skim milk powder, followed by incubation for 20 hat $37^{\circ} \mathrm{C}$ until the formation of curds. The bulk starter culture was prepared by inoculating $10 \%(\mathrm{v} / \mathrm{v})$ of the mother starter culture into $100 \mathrm{~mL}$ goat milk that was added with 4\% (w/v) skim milk powder, followed by incubation for $20 \mathrm{~h}$ at $37^{\circ} \mathrm{C}$. The bulk starter culture was then used for the fermentation of goat milk in this study.

\section{Goat Milk Fermentation}

PE goat milk that was added with $4 \%$ $(\mathrm{w} / \mathrm{v})$ skim milk powder and already pasteurized at $80^{\circ} \mathrm{C}$ for 30 min was used for fermentation in this study. A completely randomized design was used in this study consisting of single and combined starter cultures as treatments. The treatments included single starter fermentation with $L$. paracasei M104 (Lp) or $P$. pentosaceus
M103 (Pp) and combined starter fermentation with $L$. paracase $i \mathrm{M} 104$ and $P$. pentosaceus $\mathrm{M} 103$ at a ratio of $1: 1(\mathrm{Lp} / \mathrm{Pp})$, in which each treatment included $6 \%(\mathrm{v} / \mathrm{v})$ of goat milk. Milk in the control treatment was fermented using yogurt starter consisting of $L$. bulgaricus and $S$. thermophilus $(\mathrm{St} / \mathrm{Lb})$ at a ratio of 1:1 $(6 \%$, $\mathrm{v} / \mathrm{v})$ of the goat milk. All fermentation processes were conducted at $37^{\circ} \mathrm{C}$ for $18 \mathrm{~h}$, and the parameters evaluated during fermentation included the physicochemical $(\mathrm{pH}$, degree of acidity, lactose, protein, and viscosity) and microbial (total LAB) qualities of the fermented goat milk.

\section{Physicochemical Analysis}

The viscosity and the contents of lactose and protein of the fermented milk were measured after the termination of fermentation, whereas the $\mathrm{pH}$ and degree of acidity were measured every $2 \mathrm{~h}$ during the fermentation process. The $\mathrm{pH}$ measurement was done according to the potentiometer method using a $\mathrm{pH}$ meter. The degree of acidity was measured using the Mann's acid test method (Hadiwiyoto, 1994). The lactose content in the fermented goat milk was measured by the titration method as described by Sudarmadji et al. (1997). The protein content was measured using the Lowry's method, with bovine serum albumin as protein standard (Plummer, 1987). Viscosity was measured as described by Tuncturk (2009) using a Brookfield digital rheometer model DV III and spindle number 62 and 63 at 60 RPM.

\section{Total LAB Content}

The total LAB content was measured by the total plate count method in MRS agar media. The sample was diluted until it reached dilution of $10^{-7}$ by mixing $1 \mathrm{~mL}$ sample with $9 \mathrm{~mL}$ of $0.85 \% \mathrm{NaCl}(\mathrm{w} / \mathrm{v})$. The final three dilutions $\left(10^{-5}, 10^{-6}\right.$, and $\left.10^{-7}\right)$ were inoculated into MRS agar media and incubated at $37^{\circ} \mathrm{C}$ for $24 \mathrm{~h}$. The total LAB content was measured based on the number of colonies grown on the media as described by Fardiaz (1993). 


\section{Data Analysis}

Physicochemical and total LAB content data were analyzed using one-way analysis of variance, followed by Duncan's multiple range test to determine the significant results (Miller, 1986). The results were considered to be significant when $\mathrm{P}$ $<0.05$.

\section{RESULTS AND DISCUSSION}

\section{pH Changes and Acidification during Fermentation}

The $\mathrm{pH}$ of the fermented goat milk was measured every $2 \mathrm{~h}$ during the process of fermentation. Results of the $\mathrm{pH}$ measurement are presented in Figure 1. As shown in Figure 1, there was a decrease in the $\mathrm{pH}$ value with an increase in the duration of fermentation. Both $\mathrm{Lp}$ and $\mathrm{Pp}$ single starter cultures, combined $\mathrm{Lp} / \mathrm{Pp}$ starter culture, and $\mathrm{St} / \mathrm{Lb}$ starter culture demonstrated acidifying capabilities decreasing the $\mathrm{pH}$ to 4.79 after $10 \mathrm{~h}$ of fermentation.

The $\mathrm{pH}$ values of goat milk at $10 \mathrm{~h}$ of fermentation using Lp, Pp, Lp/Pp, and St/Lb starter cultures were $4.74 \pm 0.15,4.82 \pm$ $0.13,4.78 \pm 0.13$, and $4.84 \pm 0.14$, respectively. Statistical analysis of these results demonstrated that the different starter culture treatments in this study had no significant effects $(\mathrm{P}<0.05)$ on the $\mathrm{pH}$ of the fermented goat milk compared with the control treatment $(\mathrm{St} / \mathrm{Lb})$. Furthermore, after $18 \mathrm{~h}$ of fermentation, the $\mathrm{pH}$ of the goat milk fermented using St/Lb, Lp, Pp, and Lp/Pp starter cultures were $4.45 \pm 0.14,4.38 \pm$ $0.13,4.41 \pm 0.10$, and $4.41 \pm 0.14$, respectively, indicating no significant changes $(\mathrm{P}>0.05)$. However, observation of the changes in $\mathrm{pH}$ values also demonstrated that the highest $\mathrm{pH}$ decrease $(0.58)$ occurred during the first $2 \mathrm{~h}$ of fermentation.

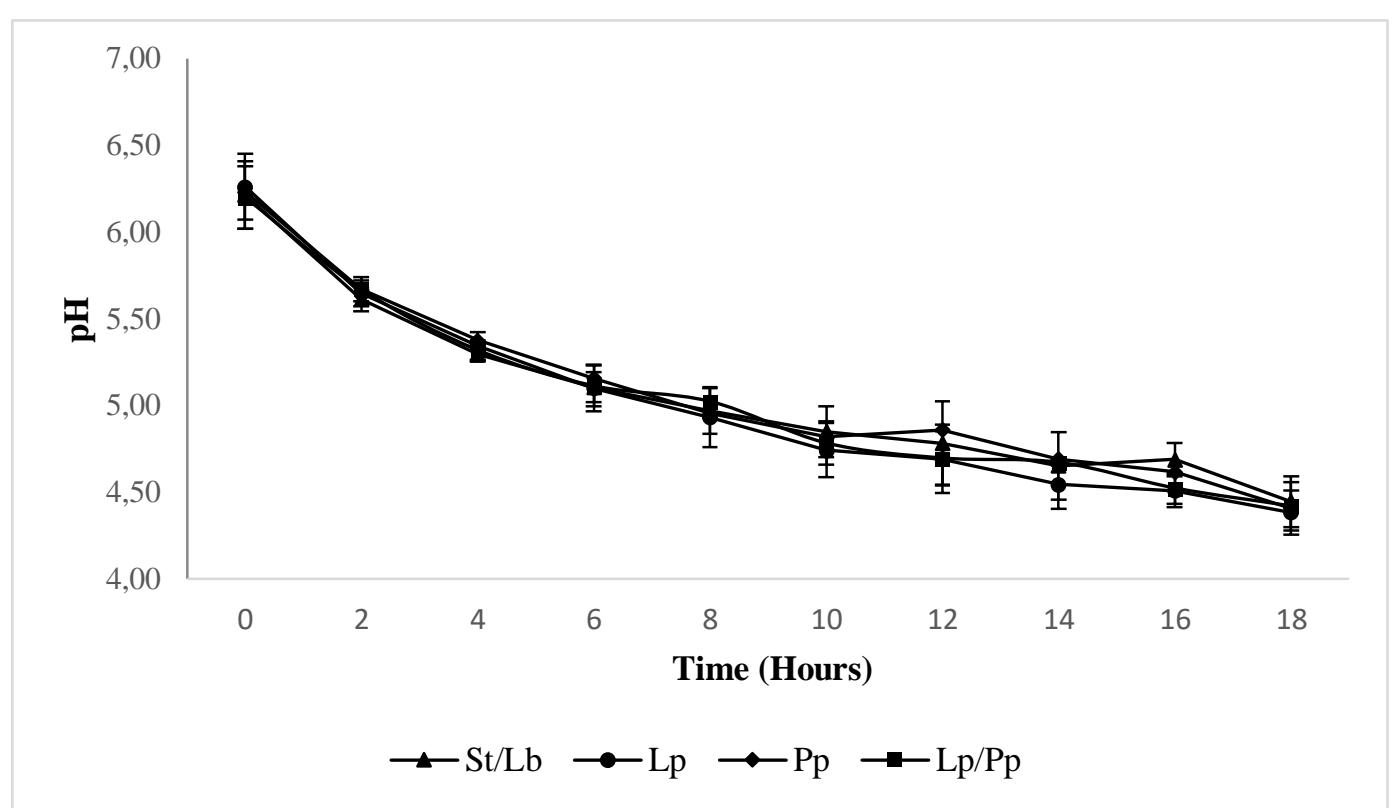

Figure 1. pH changes in goat milk fermented using four different starter cultures

Figure 2 shows the results of measurement of the degree of acidity during $18 \mathrm{~h}$ of fermentation. The degree of acidity values obtained using $\mathrm{Lp}$ and $\mathrm{Pp}$ single starter cultures were $1.24 \pm 0.06 \%$ and 1.19 $\pm 0.06 \%$, respectively. This result was similar $(\mathrm{P}>0.05)$ to that obtained using the combined fermentation of $\mathrm{Lp} / \mathrm{Pp}$ starter culture $(1.22 \pm 0.06 \%)$ and $\mathrm{St} / \mathrm{Lb}(1.21 \pm$
$0.07 \%$ ) as the control treatment. Furthermore, the average degree of acidity of the fermented goat milk in this study was $1.26 \pm 0.05 \%$, which indicates no significant difference $(\mathrm{P}>0.05)$ in the degree of acidity. The degree of acidity is considered as the major parameter in milk fermentation. The organic acids produced during fermentation, especially lactic acid and acetic acid, can 
increase the degree of acidity in milk and induce curd formation as well as provide a unique flavor to the fermented milk (Chandan, 2006; Robinson, 2002). In this study, the average degree of acidity obtained after $18 \mathrm{~h}$ of fermentation was $1.26 \pm 0.05 \%$. Widodo et al. (2013) reported that fermentation using yogurt starter (St/Lb), $L$. acidophilus FNCC-0029, and L. casei FNCC-0051 produced 1.12 $\pm 0.12 \%, 1.07 \pm$ $0.09 \%$, and $1.08 \pm 0.11 \%$ degrees of acidity in goat milk, respectively. The degree of acidity obtained in this study is consistent with the finding reported by Widodo et al. (2013) but required a longer fermentation time.

The National Standardization Agency of Indonesia has set the standard degree of acidity for fermented milk at 0.5-2.0 (SNI $2981,2009)$. Therefore, the degree of acidity obtained in this study meets the standard value, as the average degree of acidity was $0.32 \pm 0.05 \%$. The increase in the degree of acidity was similar to the decrease in the $\mathrm{pH}$ value. The average $\mathrm{pH}$ values of goat milk after 10 and $18 \mathrm{~h}$ of fermentation were 4.79 and 4.41, respectively. According to Chandan (2006), the minimum $\mathrm{pH}$ requirement for a fermented milk product is 4.6. Furthermore, a $\mathrm{pH}$ range of 4.6-4.7 would result in an isoelectric condition (Chandan, 2006), causing milk coagulation. In a previous study, Widodo et al. (2013) found that fermentation of goat milk using L. acidophilus FNCC-0029 and L. casei FNCC-0051 for $5 \mathrm{~h}$ resulted in a $\mathrm{pH}$ of 4.5. Consistent with the slow acidification rate, the decrease in $\mathrm{pH}$ in this study was also slower than that observed in other studies (Widodo et al., 2013; Widodo et al., 2016; Widodo et al., 2017). The different acidification rates and the slow $\mathrm{pH}$ decrease could be caused due to various factors such as the inoculum percentage and the incubation temperature (Shu et al., 2014).

\section{Physicochemical and Microbial Qualities of the Fermented Goat Milk}

The results of lactose and protein content measurements in the goat milk fermented using different starter cultures are presented in Table 1. As shown in the table, the lactose contents of the goat milk fermented using yogurt starter (St/Lb), Lp, $\mathrm{Pp}$, and combined $\mathrm{Lp} / \mathrm{Pp}$ starter cultures were $6.19 \pm 0.03 \%, 4.82 \pm 0.88 \%, 5.25 \pm$ $0.86 \%$, and $5.63 \pm 0.67 \%$, respectively. The statistical analysis demonstrated that the different starter cultures had no significant effects $(P>0.05)$ on the lactose content of the fermented goat milk. The average lactose content in the fermented goat milk was $5.47 \pm 0.80 \%$.

Lactose is the primary carbohydrate in milk. LAB produce a $\beta$-D-galactosidase enzyme to catalyze the breakdown of lactose into glucose and galactose and then metabolize the simple sugar through glycolysis to produce lactic acid (Hui, 1993). A decrease in lactose content during fermentation indicates the breakdown of the compound by LAB into lactic acid. The average lactose content in the fermented goat milk in this study was $5.47 \pm 0.80 \%$, which is lower than that of fresh goat milk $(6.56 \pm 0.13 \%)$. Widodo et al. (2013) reported that the lactose contents of goat milk fermented using yogurt starter culture (St/Lb), L. acidophilus FNCC-0029, and $L$. casei FNCC-0051 starter cultures for $5 \mathrm{~h}$ were $4.48 \pm 0.59 \%, 4.61 \pm 0.49 \%$, and 4.49 $\pm 0.02 \%$, respectively. The higher lactose content observed in the present study indicates the slow rate of lactose degradation, which is consistent with the slow acidification rate and the $\mathrm{pH}$ decrease as well (Figures 1 and 2).

The results of this study confirm that $L$. paracasei $\mathrm{M} 104$ and $P$. pentosaceus M103 cultures had weak acidifying abilities. According to Chandan (2006), 30\% of lactose reduction during fermentation would occur if lactose was the sole energy source for $\mathrm{LAB}$, besides the characteristic of the production of different lactase enzymes. Jiang et al. (1996) reported that lactase enzyme production can be increased if lactose was the sole energy source and significantly decreased when other energy sources, such as glucose, were available. 


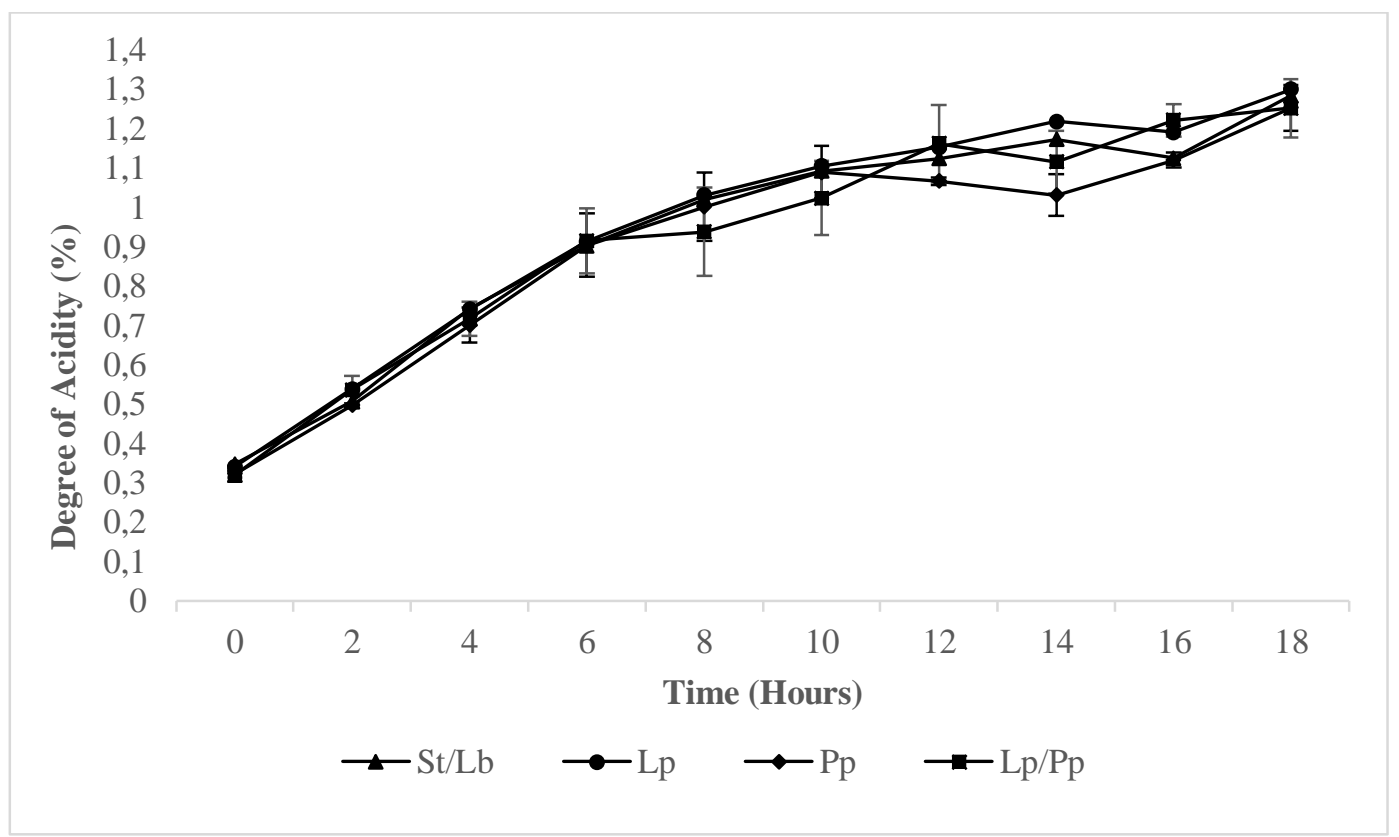

Figure 2. The degree of acidity in goat milk during $18 \mathrm{~h}$ of fermentation

Table 1. Lactose and protein levels of the fermented goat milk

${ }^{n s}$ : no significant

\begin{tabular}{lll}
\hline Starter cultures & Lactose $(\%)^{\mathrm{ns}}$ & Protein $(\%)^{\mathrm{ns}}$ \\
\hline $\mathrm{St} / \mathrm{Lb}$ & $6.19 \pm 0.03$ & $6.62 \pm 0.93$ \\
$\mathrm{Lp}$ & $4.82 \pm 0.88$ & $6.54 \pm 2.39$ \\
$\mathrm{Pp}$ & $5.25 \pm 0.86$ & $6.86 \pm 1.98$ \\
$\mathrm{Lp} / \mathrm{Pp}$ & $5.63 \pm 0.67$ & $6.76 \pm 1.50$ \\
\hline Average & $5.47 \pm 0.80$ & $6.69 \pm 1.52$ \\
\hline
\end{tabular}

Regarding the protein content of the goat milk fermented using yogurt starter (St/Lb), single Lp and Pp starter culture, and combined $\mathrm{Lp} / \mathrm{Pp}$ starter cultures, the values were $6.62 \pm 0.93 \%, 6.54 \pm 2.39 \%, 6.86 \pm$ $1.98 \%$, and $6.76 \pm 1.50 \%$, respectively (Table 1). The different starter cultures had no statistically significant effect $(\mathrm{P}>0.05)$ on the protein content of the fermented goat milk. The average protein content of the fermented goat milk in this study was $6.69 \pm$ $1.52 \%$.

The protein content of the fermented goat milk obtained in this study was higher than that reported by Widodo et al. (2013) in goat milk fermented using L. acidophilus FNCC-0029 (3.43 $\pm 0.16 \%)$ and $L$. casei FNCC-005 $(3.98 \pm 0.78 \%)$. The higher protein content in the fermented goat milk obtained in this study was caused due to the addition of $4 \%(\mathrm{w} / \mathrm{v})$ skim milk powder. In 2009, the National Standardization Agency of Indonesia (SNI) had set the minimum protein content in fermented milk products at $2.7 \%$. Hence, the protein content in the fermented goat milk in this study fulfills the standard value.

Table 2 shows the results of viscosity and total LAB measurement of the fermented goat milk in this study. The different starter cultures had no statistically significant effect $(P>0.05)$ on the viscosity and total LAB content. The viscosities of the goat milk fermented using single Lp and Pp starter cultures were $1316 \pm 603$ and $1178 \pm$ $513 \mathrm{cP}$, respectively. Furthermore, the goat milk fermented using single starter culture (Lp and Pp) had a similar viscosity as that of the goat milk fermented using the combined starter culture $(\mathrm{Lp} / \mathrm{Pp})$ and yogurt starter $(\mathrm{St} / \mathrm{Lb})$, with the viscosities being $1076 \pm$ 256 and $1299 \pm 333 \mathrm{cP}$, respectively (Table $2)$. The increase in acidity during fermentation (Figure 2) can induce the 
coagulation of milk proteins and increase the viscosity of the product compared with fresh goat milk $(1.82 \pm 0.12 \mathrm{cP})$. In a previous research, Widodo et al. (2016) reported that goat milk fermented using L. paracasei M104 and $P$. pentosaceus M103 starter cultures showed viscosities of $1075 \pm 25$ and $1475 \pm 15 \mathrm{cP}$, respectively. Viscosity of the fermented milk can be highly affected by the starter cultures used in the fermentation process. In another study conducted by Widodo et al. (2017), the viscosities of milk fermented using $L$. casei AP, L. casei AG, and $P$. acidilactici $\mathrm{BE}$ were $4035.66 \pm$ $109.69,3052.33 \pm 15.27$, and $3109.00 \pm$ $40.00 \mathrm{cP}$, respectively.

Table 2. Viscosity and total LAB content in the fermented goat milk

\begin{tabular}{|c|c|c|}
\hline Starter cultures & Viscosity $(\mathrm{cP})^{\mathrm{ns}}$ & Total LAB $(\log \mathrm{CFU} / \mathrm{mL})^{\mathrm{ns}}$ \\
\hline $\mathrm{St} / \mathrm{Lb}$ & $1299 \pm 333$ & $9.02 \pm 1.09$ \\
\hline Lp & $1316 \pm 603$ & $8.87 \pm 0.72$ \\
\hline $\mathrm{Pp}$ & $1178 \pm 513$ & $9.71 \pm 1.38$ \\
\hline $\mathrm{Lp} / \mathrm{Pp}$ & $1076 \pm 256$ & $10.67 \pm 2.36$ \\
\hline Average & $1217 \pm 395$ & $9.57 \pm 1.49$ \\
\hline
\end{tabular}

Regarding the total LAB content in the goat milk fermented using $\mathrm{Lp}$ and $\mathrm{Pp}$ as a single starter culture, combined $\mathrm{Lp} / \mathrm{Pp}$ starter culture, and yogurt starter culture $(\mathrm{St} / \mathrm{Lb})$ in this study, the values were $8.87 \pm$ $0.72,9.71 \pm 1.38,10.67 \pm 2.36$, and $9.02 \pm$ $1.09 \log$ CFU/mL, respectively (Table 2).

Furthermore, results of the statistical analysis showed no significant differences $(\mathrm{P}>0.05)$ in the average total LAB content of the final product $(9.57 \pm 1.49 \log$ $\mathrm{CFU} / \mathrm{mL}$ ). The total LAB content obtained in this study was higher than that in the previous study (Widodo et al., 2016) on goat milk fermented using $L$. paracasei M104 $(7817 \pm 0.05 \log \mathrm{CFU} / \mathrm{mL})$ and $P$. pentosaceus M103 (7719 $\pm 0.159 \mathrm{log}$ $\mathrm{CFU} / \mathrm{mL}$ ). In another study, Widodo et al. (2013) reported a total LAB content of 7.81 $\pm 0.67 \log \mathrm{CFU} / \mathrm{mL}$ in fermented milk. Furthermore, the result of the total LAB content in this study had fulfilled the national standard in Indonesia, which stated that the total LAB content of fermented milk products should be higher than $10^{7} \mathrm{CFU} / \mathrm{mL}$ (SNI, 2009), whereas Tamime and Marshall (1997) mentioned that the total LAB content should be higher than $10^{6}$ to be used as a probiotic.

\section{CONCLUSIONS}

The utilization of L. paracasei M104 and $P$. pentosaceus M103 whether as a single culture or a combined starter culture did not have any significant effect $(\mathrm{P}>0.05)$ on the physicochemical and microbial qualities of fermented goat milk. Furthermore, the produced fermented goat milk had similar qualities as those of the goat milk fermented using yogurt starter culture but required a longer fermentation time to reach the isoelectric condition.

\section{ACKNOWLEDGMENTS}

The authors would like to thank the Faculty of Animal Science, Universitas Gadjah Mada, for the research grant through Hibah Penelitian Tematik Laboratorium scheme in 2017.

\section{REFERENCES}

Badan Standardisasi Nasional. (2009). SNI Yogurt SNI 2981:2009. Jakarta: Badan Standardisasi Nasional Indonesia.

Chandan, R. C. (2006). Milk Composition, Physical and Processing 
Characteristics. In Handbook of Food Products Manufacturing: Principles, Bakery, Beverages, Cereals, Cheese, Confectionary, Fats, Fruits, and Functional Foods (A. J. Wiley \& Sons, eds.). https://doi.org/dx.doi.org/ 10.1002/9781118481301.fmatter

Fardiaz, S. (1993). Analisis Mirobiologi Pangan. Jakarta: Raja Grafindo Persada.

Hadiwiyoto, S. (1994). Teori dan Prosedur Pengujian Mutu Susu dan Hasil Olahannya. Yogyakarta: Liberty.

Haenlein, G. F. W. (2004). Goat milk in human nutrition. Small Ruminant Research, 51(2), 155-163. https:// doi.org/https://doi.org/10.1016/j.smal lrumres.2003.08.010

Hui, Y. H. (1993). Dairy Science and Technology Handbook (1 Principl). Inc. New York. USA: VCH Publishers.

Jack, R. W., Tagg, J. R., \& Ray, B. (1995). Bacteriocins of gram-positive bacteria. Microbiology Reviews, 59, 171-200.

Jennes, R. (1999). Composition of Milk (3rd ed.; R. Jennes, N. P. Wong, E. H. Marth, \& M. Keeney, eds.). New York: Aspen Publishers Inc.

Miller, R. G. (1986). Beyond ANOVA, Basics of Applied Statistics (J. Wiley $\&$ Sons, eds.). USA.

Park, Y. W., \& Haenlein, G. F. W. (2013). Milk and Dairy Products in Human Nutrition: Production, Composition, and Health (J. Wiley \& Sons, eds.). New York.
Plummer, D. T. (1987). An Introduction to Practical Biochemistry (M. Graw, ed.). London: Hill Book Company.

Robinson, R. K. (2002). Dairy Microbiology Handbook (J. Wiley \& Sons, eds.). New York.

Sudarmadji, S., Haryono, B., \& Suhardi. (1997). Prosedur Analisa untuk Bahan Makanan dan Pertanian (4th ed.). Yogyakarta: Liberty.

Tamime, A., \& Robinson, R. K. (2007). Yoghurt: Science and Technology (3rd ed.). New York: Woodhead Publishing.

Von Wright, A., \& Axelsson, L. (2012). Lactic Acid Bacteria: An Introduction. In Lactic Acid Bacteria: Microbiological and Functional Aspects (4th ed.; Taylor \& Francis Group, ed.). Florida: CRC Press.

Walstra, P., Geurts, T. J., Nooman, A., Jellema, A., \& Van Boekel, A. J. S. (1999). Dairy Technology: Principle of Milk Properties and Processes (1st ed.; Marcel Dekker, ed.). New York: CRC Press.

Walstra, P., Wouters, J. T. M., \& Geurts, T. J. (2006). Lactic Fermentations. In Dairy Science and Technology (2nd ed.; Taylor \& Francis Group, ed.). Florida: CRC Press.

Widodo, Handaka, R., Wahyuni, E., \& Taufiq, T. T. (2017). The quality of fermented milk produced using intestinal-origin lactic acid bacteria as starters. International Food Research Journal, 24, 2371-2376. 